\title{
Tristano e Isotta. La fortuna di un mito europeo, a cura di Michael Dallapiazza
}

\section{Walter Meliga}

\section{(2) OpenEdition}

1 Journals

\section{Edizione digitale}

URL: https://journals.openedition.org/studifrancesi/40283

DOI: 10.4000/studifrancesi.40283

ISSN: 2421-5856

\section{Editore}

Rosenberg \& Sellier

\section{Edizione cartacea}

Data di pubblicazione: 1 juillet 2004

Paginazione: 156-157

ISSN: 0039-2944

\section{Notizia bibliografica digitale}

Walter Meliga, «Tristano e Isotta. La fortuna di un mito europeo, a cura di Michael Dallapiazza», Studi Francesi [Online], 142 (XLVIII | I) | 2004, online dal 30 novembre 2015, consultato il 09 septembre 2021. URL: http://journals.openedition.org/studifrancesi/40283 ; DOI: https://doi.org/10.4000/studifrancesi. 40283

Questo documento è stato generato automaticamente il 9 septembre 2021.

\section{(c) (1)}

Studi Francesi è distribuita con Licenza Creative Commons Attribuzione - Non commerciale - Non opere derivate 4.0 Internazionale. 


\title{
Tristano e Isotta. La fortuna di un mito europeo, a cura di Michael Dallapiazza
}

\author{
Walter Meliga
}

\section{NOTIZIA}

Tristano e Isotta. La fortuna di un mito europeo, a cura di Michael Dallapiazza, Trieste, Edizioni Parnaso («Quademi di Hesperides. Serie Manuali», 1), 2003, pp. 363.

1 Il volume contiene diciotto contributi di studiosi italiani e stranieri sulla fortuna della storia di Tristano e Isotta, dal Medioevo a oggi, nella letteratura, nella musica e nelle arti figurative e visive. Fra i lavori si segnalano quello di Patrizia MAZZADI, Tradizione del mito di Tristano e ricezione primaria nei romanzi di Béroul, Thomas, Eilhard e Gottfried (pp. 13-26) e soprattutto quello molto ampio e ricco di bibliografia di Fabrizio CIGNI, Tristano e Isotta nelle letterature francese e italiana (pp. 29-129). 